\title{
KINERJA USAHA PEMELIHARAAN SAPI BALI (Bos sondaicus) SECARA EKSTENSIF PADA MUSIM PENGHUJAN DAN KEMARAU OLEH PETERNAK LOKAL
}

\section{The Business Performance of Bali Cattle (Bos sondaicus) in Extensive Maintenance on Rainy and Dry Seasons by The Local Farmers}

\author{
Besse Mahbuba We Tenri Gading ${ }^{*}$, Sudi Nurtini' ${ }^{2}$, dan Mujtahidah Anggriani Ummul ${ }^{2}$ \\ 1Fakultas Peternakan dan Perikanan, Universitas Sulawesi Barat, Majene \\ ${ }^{2}$ Fakultas Peternakan, Universitas Gadjah Mada, Yogyakarta \\ Email: bessemahbuba@gmail.com
}

\begin{abstract}
ABSTRAK
Penelitian ini bertujuan untuk mengetahui kinerja usaha pemeliharaan sapi Bali secara ekstensif pada musim penghujan dan kemarau oleh peternak lokal di Desa Ajuraja, Kabupaten Wajo, Sulawesi Selatan. Materi yang digunakan dalam penelitian ini yaitu tiga puluh orang peternak di Desa Ajuraja. Pengambilan sampel di Desa Ajuraja menggunakan metode purposive convinience sampling. Data diambil dengan cara survey dan wawancara langsung dengan menggunakan kuisioner yang telah dipersiapkan. Data yang di ambil meliputi karakteristik peternak, biaya dan penerimaan dari usaha pemeliharaan sapi Bali. Hasil penelitian menunjukkan bahwa pendapatan per peternak per bulan per unit ternak (UT) pada musim kemarau lebih besar dari musim penghujan yaitu sebesar Rp 115.608,00 dan musim penghujan Rp 3.562,00. Kegiatan pemeliharaan sapi Bali pada musim kemarau dan musim penghujan termasuk menguntungkan karena memiliki $\mathrm{R} / \mathrm{C}$ lebih dari 1 yaitu berturut-turut 22,01 dan 1,03.

Kata kunci: Kinerja Usaha, Sapi Bali, Peternak lokal,
\end{abstract}

\begin{abstract}
This research aims to understand the extensive performance of Bali Cattle during the wet and dry seasons by the local farmer at the village of Ajuraja in Wajo, South Sulawesi. The researcher observed thirty local farmers from Ajuraja and using purposive convenience sampling as the method. The sampling data was taken by following the method of survey and direct interview in which the researcher using questionnaires prepared prior research. Moreover, the lists of data being taken were the farmers' characteristics and thecost and revenue from the Bali Cattle performance. The result of the research showed the income on the dry season for one farmer on one month per livestock unit (LU) is higher than the income the farmer gets on wet season, with the number on dry season for Rp 115.608,00 and Rp 3.562,00 for wet season. Furthermore, the Bali Cattle performance during the dry and wet season is valuable because the number of $R / C$ are more than 1 which are 22,01 and 1,03.
\end{abstract}

Keywords: Business performance, Bali Cattle, Local Farmer

\section{PENDAHULUAN}

Sapi lokal di Indonesia telah mengalami berbagai pilihan tekanan iklim tropis basah, dan adaptasi terhadap pakan berkualitas rendah, parasit lokal dan penyakit, sehingga merupakan fenotipe adaptif baru. Permintaan sapi potong di Indonesia, baik untuk daging dan sapi hidup, saat ini melebihi kapasitas lokal untuk memasok hewan-hewan ini (Sutarno \& Setyawan, 2015) meskipun hingga 2016, populasi sapi potong masih meningkat (Badan Pusat Statistik, 2017). Sapi Bali (Bos 
sondaicus) adalah salah satu sapi lokal Indonesia yang ikut ambil bagian dalam memenuhi permintaan daging dan sapi hidup serta merupakan sekitar seperempat dari total populasi sapi di Indonesia (Lisson et al., 2010). Sapi bali memiliki kerangka dan otot yang kuat; jantan dewasa dapat memiliki berat 600-800 kg, sedangkan betina memiliki berat 500-600 kg (Martojo, 2003).

Sapi Bali sangat penting dalam usaha pertanian petani kecil di pulau-pulau timur,. Integrasi yang ketat dan saling ketergantungan antara berbagai elemen biofisik (tanah, ternak, tanaman pangan dan hijauan), anugerah sumber daya (luas dan kualitas lahan, sumber daya tenaga kerja, pasokan pakan, ketersediaan uang tunai) dan konteks sosial (sikap berisiko, agama, praktik budaya) adalah fitur karakteristik dari sistem pertanian petani kecil Indonesia Timur. Dampak variabilitas iklim temporal dan spasial serta interaksi dengan ekonomi yang lebih luas (misalnya biaya dan harga) berkontribusi pada kompleksitas masalah. Akibatnya, perubahan sistem (misalnya manajemen dan penggunaan lahan) sering mengakibatkan dampak kontra-intuitif dan kompleks, sosial serta ekonomi (Lisson et al., 2010). Petani kecil tidak menghitung pendapatan dan hasil mereka dalam memelihara sapi Bali terutama di Kabupaten Wajo di Sulawesi Selatan di mana sapi Bali menyebar luas (Entwistle \& Lindsay 2003; Sutarno 2010). Kabupaten Wajo merupakan daerah yang sangat potensial untuk menyamai permintaan daging sapi di Indonesia. Dari 100.913 sapi potong, 89.858 adalah sapi Bali (Dinas Pertanian Kabupaten Wajo, 2015).

Menurut Badan Pusat Statistik Kabupaten Wajo (2014) populasi sapi potong di Kabupaten Wajo berjumlah 89.858 ekor yang tersebar di 14 kecamatan, Kecamatan Takkalalla merupakan kecamatan dengan jumlah sapi Bali terbanyak yaitu 16.401 ekor. Penjualan ternak hanya dilakukan sewaktu-waktu apabila ada kebutuhan keluarga peternak yang sangat mendesak. Sistem penjualan yang tidak rutin disebabkan karena pemeliharaan ternak sapi Bali oleh peternak bukan merupakan usaha pokok dengan tujuan penjualan rutin, namun dijadikan sebagai tabungan. Harga jual ternak sapi Bali yang berlaku di daerah tersebut didasarkan pada umur dan jenis kelamin serta performan ternak. Berdasarkan latar belakang diatas peneliti tertarik untuk meneliti kinerja usaha pemeliharaan sapi Bali secara ekstensif saat musim penghujan dan kemarau pada peternak lokal di Desa Ajuraja, Takkalalla, Wajo, Sulawesi Selatan.

\section{METODE}

Penelitian ini dilakukan di Desa Ajuraja, Kecamatan Takkalalla, Kabupaten Wajo. Jumlah responden adalah 30 orang peternak sapi Bali di daerah penelitian. Pengambilan sampel dilokasi penelitian dilakukan dengan metode purposive convinience sampling yaitu pengambilan sampel yang sesuai ketentuan atau persyaratan sampel dari populasi tertentu yang paling mudah dijangkau dan didapatkan yaitu telah memelihara sapi minimal 2 tahun dan milik sendiri.

Metode yang digunakan dalam penelitian ini adalah metode survei dengan mengajukan pertanyaan (kuisioner) yang telah dibuat sebelumnya sesuai dengan tujuan penelitian. Pelaksanaan penelitian meliputi dua tahap, tahap pertama yaitu mencari informasi terkait dengan penelitian dan menetukan lokasi penelitian. Tahap kedua yaitu pengumpulan data primer dan data sekunder.

Analisis data meliputi total penerimaan dan total biaya yang dikeluarkan peternak pada musim kemarau dan musim penghujan. Pendapatan yang diperoleh peternak dihitung dengan menggunakan selisih antara total penerimaan dengan total biaya yang dikeluarkan pada musim penghujan dan musim kemarau. Besarnya pendapatan dari suatu usaha dirumuskan (Soekartawi, 1995):

$$
\mathrm{Pd}=\mathrm{TR}-\mathrm{TC}
$$




\section{Keterangan: \\ $\mathrm{Pd}=$ Pendapatan peternak $(\mathrm{Rp} / \mathrm{bln})$ \\ $\mathrm{TR}=$ Total Revenue / Total penerimaan peternak $(\mathrm{Rp} / \mathrm{bln})$ \\ $\mathrm{TC}=$ Total cost / Total biaya yang dikeluarkan peternak (Rp/bln)}

\section{HASIL DAN PEMBAHASAN}

Kondisi udara di Desa Ajuraja, Takkalalla berkisar antara 29ํㅡ sampai 31ํㅡ. Bulan Juli 2014 sampai dengan bulan Januari 2015 yaitu selama tujuh bulan, peternak tidak mengolah lahan pertanian karena keterbatasan air dan lahan pertanian peternak hanya mengandalkan air hujan, sehingga lahan pertanian hanya dimanfaatkan sebagai lahan penggembalaan sapi. Peternak di lokasi penelitian mulai mengolah lahan pertanian pada bulan Februari 2015 setelah pada bulan Januari 2015 adanya curah hujan sebesar 81mm. Peternak memanfaatkan adanya hujan tersebut untuk membasahi lahan pertanian mereka, sehingga pada bulan Februari 2015 peternak mulai mengolah lahan pertanian dan pada bulan juni 2015 peternak memanen hasil pertanian (padi). Total waktu yang digunakan peternak mulai dari mengolah lahan sampai dengan memanen hasil pertanian adalah lima bulan. Selama peternak mengolah lahan pertanian miliknya sapi yang dimiliki dipindahkan merumput ke lokasi yang telah disiapkan yaitu sawah yang sengaja disisihkan, kebun yang tidak diolah dan lahan yang telah disewa. Lahan pertanian (sawah) pada musim penghujan umumnya ditanami tanaman pangan yaitu padi, pada musim kemarau lahan pertanian tidak diolah karena lahan pertanian hanya mengandalkan air hujan dan tidak ada irigasi sehingga pada musim kemarau tanaman pangan tidak dapat tumbuh. Lahan pertanian pada musim kemarau ditumbuhi rumput liar yang dijadikan sebagai pakan ternak.

Masyarakat di lokasi penelitian umumnya telah memelihara ternak sapi secara turun temurun dan menjadikan sapi sebagai tabungan keluarga yang sewaktu-waktu dapat dijual jika peternak membutuhkan uang untuk kebutuhan yang mendesak. Sapi pada musim kemarau merumput dilahan pertanian baik siang maupun malam hari dengan mengkonsumsi rumput liar yang tumbuh di lahan pertanian. Musim penghujan sapi kekurangan lahan untuk merumput karena lahan yang biasanya dijadikan sebagai tempat merumput ditanami tanaman pangan. Untuk tetap menjamin ketersediaan pakan pada musim penghujan, peternak menyisihkan sebagian kecil lahan pertanian/sawah miliknya untuk digunakan sebagai tempat merumput sapi Bali, sawah kemudian diberi patok sebagai pembatas antara lahan yang ditanami dan lahan yang disisihkan.

Peternak juga telah menyiapkan kebun yang sengaja tidak diolah untuk digunakan sebagai tempat merumput sapi. Peternak yang tidak memiliki lahan untuk menggembalakan sapi miliknya akan melakukan sewa lahan, lahan yang disewa oleh peternak. Kurangnya lahan yang dapat dijadikan sebagai tempat menggembalakan sapi dan kepemilikan lahan pertanian yang luas menjadi alasan peternak menyisihkan lahan pertanian miliknya, agar sapi tetap mendapatkan hijauan pada musim penghujan. Peternak juga menganggap menyisihkan lahan pertanian miliknya untuk penggembalaan sapi lebih menguntungkan jika dibandingkan dengan menyewa lahan.

Sistem pemeliharaan sapi yang dipelihara oleh peternak masih bersifat tradisional dan tidak dikandangkan atau bersifat ekstensif. Pemeliharaan secara ekstensif yaitu ternak digembalakan secara alami untuk merumput sendiri baik siang maupun malam hari, tanpa kandang dan pemberian pakan tambahan. Penjualan sapi Bali yang dilakukan oleh peternak tidak menentu, penjualan dilakukan apabila peternak memerlukan dana dan apabila ada konsumen yang mau membeli. Sapi banyak terjual pada musim kemarau, salah satu alasan sapi banyak dijual peternak pada musim kemarau karena musim kemarau lebih panjang sehingga kebutuhan peternak lebih besar, tetapi 
tidak ada penghasilan dari lahan pertanian sehingga memilih untuk menjual sapi Bali untuk memenuhi kebutuhannya.

\section{Karakteristik Responden}

Karakteristik responden merupakan salah satu aspek penting yang turut berpengaruh dalam kegiatan usaha peternakan. Dalam penelitian ini karakteristik responden yang dimaksud adalah umur, tingkat pendidikan, pekerjaan, pengalaman beternak, jumlah tanggungan keluarga, jumlah kepemilikan ternak dan luas lahan yang dimiliki yang tersaji pada Tabel 1. Responden dalam hal ini yaitu musim kemarau juga sama dengan responden pada musim penghujan.

Berdasarkan hasil penelitian diperoleh data umur peternak mulai dari 24 tahun sampai 62 tahun dengan rata-rata 44,1 tahun yang menunjukkan bahwa semua responden tergolong ke dalam usia produktif (Tabel 1). Tingkat pendidikan sebagian peternak masih tergolong rendah yakni $43,34 \%$ dari responden peternak belum memenuhi wajib belajar 9 tahun yang telah ditetapkan pemerintah sesuai dengan Peraturan Pemerintah No. 47 Tahun 2008 tentang wajib belajar. Pekerjaan pokok merupakan pekerjaan yang dilakukan terbanyak atau yang utama dilakukan. Pekerjaan utama memberikan penghasilan terbesar. Berdasarkan hasil penelitian diperoleh data bahwa semua peternak memiliki mata pencaharian utama adalah sebagai petani. Hal ini menunjukkan bahwa sub sektor peternakan belum merupakan pekerjaan pokok, namun sebagai pekerjaan sampingan.

Tabel 1. Karakteristik peternak responden

\begin{tabular}{lc}
\hline \hline Kategori & Rata-rata \\
\hline Umur (th) & $44,1 \pm 8,87$ \\
Pendidikan (\%) & 16,67 \\
1. Buta huruf & 26,67 \\
2. SD & 50 \\
3. SMP & 6,67 \\
4. SMA & 100 \\
Pekerjaan pokok (\%) & $16,9 \pm 7,38$ \\
$\quad$ Petani & $4,96 \pm 1,54$ \\
Pengalaman beternak (th) & \\
Jumlah keluarga (orang) & $3,01 \pm 1,03$ \\
Luas lahan (Ha) & $0,31 \pm 0,51$ \\
1. Sawah & $8,36 \pm 5,21$ \\
2. Kebun & $6,341 \pm 4,22$ \\
Kepemilikan sapi (ekor) & \\
Kepemilikan sapi (UT) &
\end{tabular}

Berdasarkan hasil penelitian diperoleh data umur peternak mulai dari 24 tahun sampai 62 tahun dengan rata-rata 44,1 tahun $\pm 8,87$ yang menunjukkan bahwa semua responden tergolong ke dalam usia produktif. Tingkat pendidikan sebagian peternak masih tergolong rendah yakni 43,34\% dari responden peternak belum memenuhi wajib belajar 9 tahun yang telah ditetapkan pemerintah sesuai dengan Peraturan Pemerintah No.47 Tahun 2008 tentang wajib belajar. Pekerjaan pokok merupakan pekerjaan yang dilakukan terbanyak atau yang utama dilakukan. Pekerjaan utama memberikan penghasilan terbesar. Berdasarkan hasil penelitian diperoleh data bahwa semua peternak memiliki mata pencaharian utama adalah sebagai petani. Hal ini menunjukkan bahwa sub sektor peternakan belum merupakan pekerjaan pokok, namun sebagai pekerjaan sampingan.

Lahan yang dimiliki peternak terdiri atas 2 macam yaitu lahan pertanian atau sawah dan kebun. Lahan pertanian sawah yang dimiliki peternak lebih luas jika dibandingkan dengan luas 
kebun, hal ini karena petenak memiliki pekerjaan utama sebagai petani. Musim kemarau lahan pertanian tidak diolah karena lahan pertanian merupakan tanah tadah hujan yang belum memiliki saluran irigasi dan hanya mengandalkan air hujan sehingga tidak dapat ditumbuhi tanaman pangan. Kondisi ini menyebabkan lahan pertanian pada musim kemarau dimanfaatkan sebagai tempat penggembalaan sapi. Musim penghujan lahan pertanian diolah dan ditanami tanaman pangan yaitu sawah ditanami padi dan kebun umumnya ditanami singkong. Hal ini menyebabkan lahan penggembalaan dan hijauan pakan ternak menjadi berkurang. Untuk tetap menjamin ketersediaan hijauan pakan, sebagian peternak menyisihkan sebagian kecil lahan sawah dan seluruh kebun miliknya untuk digunakan sebagai tempat merumput sapi Bali. Lahan pertanian yang disisihkan sengaja tidak diolah agar sapi Bali yang dimiliki dapat merumput dilokasi tersebut pada musim penghujan sehingga kebutuhan hijauan pakan ternaknya dapat terpenuhi. Komposisi kepemilikan sapi peternak responden bervariasi yang terdiri dari pedet sampai dewasa. Pemilikan ternak responden secara rinci dapat dilihat pada Tabel 2.

Tabel 2. Komposisi sapi peternak responden

\begin{tabular}{lccc}
\hline \multicolumn{1}{c}{ Sapi } & Rata-rata/ & Rata-rata/ & Komposisi \\
Bali & peternak & peternak & \\
& (Ekor) & (UT) & 79,37 \\
Dewasa & 5,03 & 5,03 & 14,98 \\
Muda & 1,9 & 0,95 & 5,65 \\
Pedet & 1,43 & 0,35 & 100 \\
\hline Jumlah & $8,36 \pm 5,21$ & $6,341 \pm 4,22$ & 1.42 \\
\hline
\end{tabular}

Kepemilikan ternak khususnya sapi jantan dewasa lebih sedikit jika dibandingkan dengan sapi betina dewasa, ini disebabkan karena peternak kebanyakan menjual sapi jantan miliknya. Permintaan terhadap sapi jantan lebih tinggi dibandingkan dengan sapi betina. Sapi jantan selain banyak disembelih di RPH juga banyak disembelih ketika acara adat (pesta pernikahan, aqiqah) dan ketika idul Qurban.

\section{Analisis Pendapatan usaha pemeliharaan sapi Bali}

Pendapatan dari usaha pemeliharaan sapi Bali diperoleh dengan memperhitungkan nilai penerimaan pedet dan penjualan ternak pada musim kemarau dan musim penghujan. Perhitungan biaya pemeliharaan sapi Bali yaitu meliputi kehilangan nilai ternak pada musim kemarau dan musim penghujan, biaya pakan pada musim penghujan dan biaya peralatan yaitu tali dan tempat minum sapi pada musim kemarau.

\section{Penerimaan}

Penerimaan peternak berasal dari nilai pedet dan penjualan ternak Di daerah penelitian peternak tidak memperhitungkan kenaikan nilai ternak yang dimiliki sebagai penerimaan karena peternak umumnya memelihara sapi sampai tua bahkan sampai mati, dan baru akan menjual sapi ketika membutuhkan uang, sehingga penerimaannya hanya berasal dari nilai pedet yang lahir pada musim kemarau dan penghujan dan penjualan sapi Bali pada musim kemarau dan penghujan. Nilai pedet diperoleh dari harga pedet yang lahir pada musim kemarau dan musim penghujan. Nilai pedet pada musim kemarau sedikit lebih mahal dibandingkan pada musim penghujan karena pada musim penghujan pedet rawan terkena penyakit. Nilai pedet dan penjualan ternak dapat dilihat pada Tabel 3 dan 4. 
Nilai jual sapi diperoleh dengan menghitung harga sapi yang di jual pada musim kemarau dan penghujan. Penjualan sapi lebih banyak pada musim kemarau dibandingkan pada musim penghujan tetapi nilai jual sapi pada musim kemarau relatif lebih rendah dibandingkan pada musim penghujan. Musim kemarau peternak lebih membutuhkan uang karena musim kemarau tidak ada pemasukan dari lahan pertanian yang menyebabkan penjualan sapi merupakan sumber penghasilan satusatunya, sehingga harga relatif lebih lebih murah dari harga pada musim penghujan.

Tabel 3. Nilai pedet yang dimiliki peternak responden

\begin{tabular}{lrr}
\hline \multicolumn{1}{c}{ Keterangan } & Musim kemarau & Musim penghujan \\
\hline Total pedet lahir hidup (Ekor) & 23 & 20 \\
Rata-rata total pedet lahir $\quad$ hidup & 0,77 & 0,67 \\
(Ekor/peternak) & $1.608 .695,00$ & $1.600 .000,00$ \\
Rata-rata nilai pedet (Rp/ekor) & $37.000 .000,00$ & $32.000 .000,00$ \\
Total nilai pedet (Rp) & $5.285 .714,00$ & $6.400 .000,00$ \\
Rata-rata nilai pedet (Rp/bulan) & $176.190,00$ & $213.000,00$ \\
\hline
\end{tabular}

Penjualan sapi Bali tidak menentu, peternak akan menjual sapi Bali miliknya jika peternak membutuhkan uang seperti ketika menikahkan anaknya, membeli peralatan rumah tangga, membeli motor dan jika ada konsumen yang mau membeli. Konsumen yang datang untuk membeli sapi tujuannya bermacam-macam yaitu untuk disembelih ketika Idul Qurban, untuk acara pernikahan yakni dijadikan sebagai seserahan (Alukalu) dan aqiqah. Sebagian kecil peternak juga akan menjual sapi miliknya jika sapi Bali tersebut sudah tua dan bobot badannya semakin kurus.

Tabel 4. Penjualan sapi peternak responden

\begin{tabular}{|c|c|c|}
\hline Keterangan & Musim kemarau & Musim penghujan \\
\hline Total sapi yang dijual (Ekor) & 13 & 8 \\
\hline $\begin{array}{l}\text { Rata-rata total sapi yang dijual } \\
\text { (Ekor/peternak) }\end{array}$ & 0,43 & 0,27 \\
\hline Rata-rata nilai jual sapi (Rp/ekor) & 7.538.461,00 & $8.000 .000,00$ \\
\hline Total nilai jual sapi (Rp) & $98.000 .000,00$ & $64.000 .000,00$ \\
\hline Total nilai sapi yang dijual (Rp/bulan) & $14.000 .000,00$ & $12.800 .000,00$ \\
\hline $\begin{array}{l}\text { Rata-rata total nilai sapi yang dijual } \\
\text { (Rp/bulan/peternak) }\end{array}$ & $466.667,00$ & $426.667,00$ \\
\hline
\end{tabular}

\section{Biaya}

Biaya yang dihitung ada 3 macam yaitu biaya mortalitas ternak, biaya peralatan dan biaya pakan. Rata-rata biaya pemeliharaan pada musim kemarau dan penghujan dapat dilihat pada Tabel 5,6 dan 7.

\section{Biaya mortalitas ternak.}

Biaya mortalitas ternak merupakan biaya penerimaan peternak yang hilang yang berasal dari ternak karena mati, maka perhitungan nilai mortalitas ternak dan dimasukkan pada komponen biaya. Kematian pedet banyak terjadi ketika musim kemarau yang disebabkan karena pedet yang tidak dapat lahir dengan normal serta lokasi penggembalaan sapi Bali yang jauh dari jangkauan peternak dan peternak yang tidak mengetahui bahwa akan terjadi kelahiran pedet, sehingga peternak tidak dapat membantu kelahiran pedet tersebut.

Kematian pedet juga disebabkan karena pedet tidak diikat sehingga ruang geraknya tidak dibatasi yang menyebabkan pedet berkeliaran kemana-kemana dan di mangsa oleh binatang buas. Berbeda dengan musim penghujan yaitu peternak pada sore hari memindahkan ternaknya dari lahan 
penggembalaan untuk digembalakan di sekitar rumah, sehingga pengawasan terhadap pedet yang akan lahir lebih besar di musim penghujan.

Tabel 5. Biaya mortalitas ternak

\begin{tabular}{lrr}
\hline \hline \multicolumn{1}{c}{ Keterangan } & Musim kemarau & Musim penghujan \\
\hline Pedet yang mati (ekor) & 3 & 1 \\
Rata-rata nilai pedet yang mati (Rp/ekor) & $1.500 .000,00$ & $1.500 .000,00$ \\
Total nilai pedet yang mati (Rp) & $4.500 .000,00$ & $1.500 .000,00$ \\
Nilai pedet yang mati (Rp/bulan) & $642.857,00$ & $300.000,00$ \\
Rata-rata nilai pedet yang mati & $21.429,00$ & $10.000,00$ \\
(Rp/bulan/peternak) & & \\
\hline
\end{tabular}

Musim penghujan pedet diikat untuk membatasi ruang gerak pedet dan tidak mengganggu lahan pertanian, sehingga tidak dapat berkeliaran kemana-mana dan binatang buas tidak bisa memangsa pedet tersebut karena berada dalam lingkungan induknya. Hal ini sependapat dengan Meta (2018) yang mengatakan bahwa pola pemeliharaan Sapi Bali secara tradisional berdampak pada penurunan angka kelahiran, dan cenderung meningkatkan angka mortalitas setiap tahunnya, Susanti (2015) menambahkan bahwa penyebab tingginya angka kematian disebabkan karena kurangnya penanganan pedet saat dilahirkan. Secara umum apabila peternak telah melihat ciri-ciri Induk sapi yang akan melahirkan, peternak akan membawa induk tersebut untuk digembalakan disekitar rumah agar lebih mudah di awasi dan dibantu ketika akan melahirkan, sehingga mengurangi kematian pedet.

\section{Biaya peralatan.}

Biaya peralatan tali yang dikeluarkan peternak tersaji pada Tabel 6. dan biaya peralatan tempat minum tersaji pada Tabel 7. Peralatan yang digunakan oleh peternak adalah tali dan tempat minum yaitu ember dan ban bekas. Tali digunakan untuk mengikat sapi dan tempat minum (ember dan ban bekas) digunakan untuk memberikan minum sapi hanya pada musim kemarau.

Tabel 6. Biaya peralatan (tali)

\begin{tabular}{|c|c|c|}
\hline Keterangan & Musim kemarau & Musim penghujan \\
\hline Jumlah ternak (ekor) & 221 & 260 \\
\hline Total panjang tali yang dibeli (m) & 2210 & 1.300 \\
\hline $\begin{array}{l}\text { Rata-rata total panjang tali yang dibeli } \\
(\mathrm{m} / \text { peternak) }\end{array}$ & 73,67 & 43,33 \\
\hline Rata-rata biaya tali $(\mathrm{Rp} / \mathrm{m})$ & $1.750,00$ & $1.750,00$ \\
\hline Total biaya perlatan (Rp) & $3.867 .500,00$ & $2.275 .000,00$ \\
\hline Biaya tali yang dibeli (Rp/bulan) & $552.500,00$ & $455.000,00$ \\
\hline $\begin{array}{l}\text { Rata-rata biaya tali yang dibeli } \\
\text { (Rp/bulan/peternak) }\end{array}$ & $18.416,00$ & $15.166,00$ \\
\hline
\end{tabular}

Tali digunakan untuk mengikat sapi agar tidak merumput dan berkeliaran terlalu jauh serta tidak mengganggu pemukiman warga. Tetapi pada musim kemarau pedet tidak diikat sehingga pedet sering mengganggu tanaman warga, untuk mencegah hal tersebut, warga perlu memagari rumah dan memagari tanaman. Rata-rata total biaya peralatan pada musim kemarau lebih besar dari musim penghujan karena walaupun peternak pada musim penghujan mengeluarkan biaya untuk mengikat pedet yang sebelumnya tidak diikat pada musim kemarau, tetapi panjang tali pada musim penghujan lebih pendek dari musim kemarau yaitu 5 meter pada musim penghujan dan 10 meter pada musim 
kemarau. Tali pada musim penghujan lebih pendek bertujuan untuk membatasi ruang gerak sapi baik sapi dewasa, sapi muda dan pedet agar tidak mengganggu lahan pertanian yang telah ditanami padi. Hal ini seperti yang diungkapkan Page et al., (2013) yang mengatakan bahwa pada musim penghujan sapi ditambatkan untuk menghindari sapi makan dan menginjak tanaman padi.

Biaya peralatan (tempat minum) hanya dikeluarkan oleh peternak pada musim kemarau, pada musim penghujan peternak tidak mengeluarkan biaya untuk tempat minum (Tabel 7). Musim kemarau peternak memberikan air minum untuk sapi agar kebutuhan air minum sapi mereka tetap terpenuhi. Musim kemarau peternak akan membawakan air minum untuk sapi di sawah dengan cara mallempa wae yaitu memikul air dengan menggunakan ember, untuk peternak yang memiliki banyak sapi mereka lebih memilih untuk menggiring sapi miliknya untuk minum di sekitar rumah peternak dengan menyediakan tempat minum berupa ban mobil bekas yang sudah tidak digunakan, karena jika harus mallempa wae mereka membutuhkan lebih banyak tenaga. Rata-rata total biaya tempat minum ember dan ban bekas yang dikeluarkan adalah berturut-turut Rp 3.509,00/bulan/peternak dan Rp 13.095,00/bulan/peternak.

Tabel 7. Biaya peralatan tempat minum pada musim kemarau

\begin{tabular}{lr}
\hline \hline \multicolumn{1}{c}{ Keterangan } & Musim kemarau \\
\hline Total ember (Buah) & 67 \\
Rata-rata harga ember (per buah) & $11.000,00$ \\
Total harga ember (Rp) & $737.000,00$ \\
Biaya ember yang dibeli (Rp/bulan) & $105.285,00$ \\
Rata-rata biaya ember yang dibeli (Rp/bulan/peternak) & $3.509,00$ \\
Ban Bekas & \\
Total ban bekas (Buah) & 22 \\
Rata-rata harga ban bekas (per buah) & $125.000,00$ \\
Total harga ban bekas (Rp) & $2.750 .000,00$ \\
Biaya ban bekas yang dibeli (Rp/bulan) & $392.857,00$ \\
Rata-rata biaya ban bekas yang dibeli (Rp/bulan/peternak) & $13.095,00$ \\
\hline
\end{tabular}

Biaya peralatan (tempat minum) hanya dikeluarkan oleh peternak pada musim kemarau, pada musim penghujan peternak tidak mengeluarkan biaya untuk tempat minum. Musim kemarau peternak memberikan air minum untuk sapi agar kebutuhan air minum sapi mereka tetap terpenuhi. Musim kemarau peternak akan membawakan air minum untuk sapi di sawah dengan cara mallempa wae yaitu memikul air dengan menggunakan ember, untuk peternak yang memiliki banyak sapi mereka lebih memilih untuk menggiring sapi miliknya untuk minum di sekitar rumah peternak dengan menyediakan tempat minum berupa ban mobil bekas yang sudah tidak digunakan, karena jika harus mallempa wae mereka membutuhkan lebih banyak tenaga. Rata-rata total biaya tempat minum ember dan ban bekas yang dikeluarkan adalah berturut-turut Rp 3.509,00/bulan/peternak dan Rp 13.095,00/bulan/peternak.

\section{Biaya pakan.}

Biaya pakan yang dikeluarkan oleh peternak opportunity cost dan biaya sewa lahan. Biaya kesempatan (opportunity cost) yaitu biaya pakan yang berasal dari lahan pertanian yang disisihkan, cara mendapatkan biaya pakan yaitu dengan menghitung pendapatan hasil pertanian dari lahan yang disisihkan tersebut. Biaya sewa lahan merupakan biaya yang dikeluarkan peternak untuk menyewa lahan yang kemudian dijadikan sebagai tempat penggembalaan sapi Bali. Biaya pakan yang dikeluarkan oleh peternak hanya pada musim penghujan seperti yang tersaji pada Tabel 8. 
Tabel 8. Biaya pakan musim penghujan dari lahan yang disisihkan dan disewa

\begin{tabular}{llcccr}
\hline \hline \multicolumn{1}{c}{ Keterangan } & \multicolumn{1}{c}{$\begin{array}{c}\text { Sawah } \\
(\mathrm{Ha})\end{array}$} & $\begin{array}{c}\text { Kebun } \\
(\mathrm{Ha})\end{array}$ & $\begin{array}{c}\text { Sewa lahan } \\
(\mathrm{Ha})\end{array}$ & Total \\
\hline Lahan & Luas & 8,7 & 9,5 & 4 & 22,2 \\
& Rata-rata & 0,29 & 0,31 & 0,13 & 0,74 \\
& (per peternak) & & & & \\
\multirow{2}{*}{ Biaya } & Jumlah* & $15.506 .900,00$ & $1.916 .000,00$ & $530.000,00$ & $17.952 .900,00$ \\
(Rp/bulan) & Rata-rata & $516.897,00$ & $63.867,00$ & $17.667,00$ & $598.431,00$ \\
& (per peternak) & & & & \\
\hline
\end{tabular}

Biaya pakan dikeluarkan oleh peternak hanya pada musim penghujan. Biaya pakan terbagi dua yaitu berasal dari lahan pertanian dan sewa lahan. Lahan pertanian yaitu berupa sawah dan kebun yang sengaja disisihkan agar dapat dimanfaatkan sebagai tempat merumput sapi pada musim penghujan agar kebutuhan hijauan pakan tetap terpenuhi walaupun tidak sebanyak pada musim kemarau.

Biaya sewa lahan yaitu biaya yang dikeluarkan peternak untuk menyewa lahan, lahan yang disewa kemudian digunakan sebagai tempat merumput sapi pada musim penghujan, walaupun peternak menyewa lahan tersebut selama satu tahun, tetapi hanya memanfaatkan lahan tersebut pada musim penghujan karena peternak menganggap bahwa menggembalakan sapi di lahan pertanian pada musim kemarau lebih dekat dari pemukiman warga dibandingkan dengan di lahan yang disewa yang letaknya lebih jauh.

\section{Pendapatan}

Pendapatan yang diperoleh peternak dari usaha ternak sapi Bali didapatkan dari total ratarata pendapatan peternak dikurangi total rata-rata biaya yang dikeluarkan oleh peternak dalam satu musim. Pendapatan peternak yang diperoleh dari pemeliharaan sapi Bali terlampir pada Tabel 9 dan Tabel 10.

Tabel 9. Rata-rata biaya, penerimaan dan pendapatan per peternak

\begin{tabular}{lrr}
\hline \hline \multicolumn{1}{c}{ Keterangan } & $\begin{array}{c}\text { Musim kemarau } \\
\text { (Rp/Bulan } \\
\text { /peternak) }\end{array}$ & $\begin{array}{c}\text { Musim penghujan } \\
\text { (Rp/Bulan/ } \\
\text { peternak) }\end{array}$ \\
\hline $\begin{array}{l}\text { A. Penerimaan } \\
\text { Penjualan sapi Bali }\end{array}$ & $466.667,00$ & $426.667,00$ \\
Nilai pedet & $176.190,00$ & $213.000,00$ \\
Total penerimaan & $\mathbf{6 4 2 . 8 5 7 , 0 0}$ & $\mathbf{6 3 9 . 6 6 7 , 0 0}$ \\
$\begin{array}{l}\text { B. Biaya } \\
\text { Biaya variabel }\end{array}$ & & \\
$\begin{array}{l}\text { Biaya mortalitas ternak } \\
\text { Biaya peralatan (tali) }\end{array}$ & $21.429,00$ & $10.000,00$ \\
Biaya peralatan (tempat minum) & $18.417,00$ & $15.167,00$ \\
Biaya pakan & $16.604,00$ & 0 \\
Biaya tetap & & $598.431,00$ \\
- & & - \\
Total biaya & & $\mathbf{6 2 3 . 5 9 8 , 0 0}$ \\
\hline Rata-rata pendapatan peternak & $\mathbf{5 6 . 4 5 0 , 0 0}$ & $\mathbf{1 6 . 0 6 9 , 0 0}$ \\
\hline
\end{tabular}

Pendapatan peternak lebih banyak pada musim kemarau dibandingkan pada musim penghujan, karena pada musim penghujan peternak mengeluarkan biaya pakan. Biaya pakan merupakan biaya terbesar yang dikeluarkan peternak. Biaya pakan berasal dari lahan pertanian yang 
disisihkan untuk ditempati merumput sapi. Pada musim kemarau peternak tidak mengeluarkan biaya pakan, karena sapi mendapatkan hijauan pakan dari di lahan pertanian peternak yang tidak diolah. Analisis R/C Ratio merupakan perbandingan antara penerimaan dan biaya. R/C ratio digunakan untuk mengetahui apakah usaha peternakan sapi Bali menguntungkan atau rugi. Hasil analisis $\mathrm{R} / \mathrm{C}$ ratio berdasarkan pendapatan peternak yaitu pada musim kemarau 12,62 dan 1,02 pada musim penghujan (Tabel 9). Hasil tersebut menunjukkan bahwa usaha peternakan sapi menguntungkan. R/C Ratio musim kemarau jauh lebih besar jika dibandingkan pada musim penghujan karena pada musim kemarau peternak tidak mengeluarkan biaya untuk pakan ternak, pada musim penghujan peternak mengeluarkan biaya pakan dari lahan pertanian yang disisihkan dan melakukan sewa lahan.

Pendapatan peternak lebih banyak pada musim kemarau dibandingkan pada musim penghujan, karena pada musim penghujan peternak mengeluarkan biaya pakan. Biaya pakan merupakan biaya terbesar yang dikeluarkan peternak. Biaya pakan berasal dari lahan pertanian yang disisihkan untuk ditempati merumput sapi. Pada musim kemarau peternak tidak mengeluarkan biaya pakan, karena sapi mendapatkan hijauan pakan dari di lahan pertanian peternak yang tidak diolah.

Tabel 10. Rata-rata biaya, penerimaan dan pendapatan per UT per peternak

$\begin{array}{ccc} & \text { Musim } & \text { Musim penghujan } \\ \text { Keterangan } & \text { kemarau } & \text { (Rp/UT/Bulan/peternak) } \\ & \text { (Rp/UT/Bulan/peternak) } & \end{array}$

\begin{tabular}{lrr}
\hline A. Penerimaan & & \\
Penjualan sapi Bali & $92.428,00$ & $68.787,00$ \\
Nilai pedet & $28.649,00$ & $37.785,00$ \\
Total penerimaan & $\mathbf{1 2 1 . 0 7 7 , 0 0}$ & $\mathbf{1 0 6 . 5 7 2 , 0 0}$ \\
B. Biaya & & \\
Biaya variabel & $4.115,00$ & $1.025,00$ \\
Biaya mortalitas ternak & $2.948,00$ & $2.421,00$ \\
Biaya tali & $2.526,00$ & 0 \\
Biaya tempat minum & 0 & $100.589,00$ \\
Biaya pakan & - & \\
Biaya tetap & $\mathbf{5 . 4 7 5 , 0 0}$ & - \\
- & $\mathbf{1 1 1 . 4 8 8 , 0 0}$ & $\mathbf{1 0 3 . 0 1 1 , 0 0}$ \\
\hline Total biaya & & $\mathbf{2 . 5 3 7 , 0 0}$ \\
\hline Rata-rata pendapatan peternak &
\end{tabular}

Analisis R/C Ratio merupakan perbandingan antara penerimaan dan biaya. R/C ratio digunakan untuk mengetahui apakah usaha peternakan sapi Bali menguntungkan atau rugi. Hasil analisis $\mathrm{R} / \mathrm{C}$ ratio berdasarkan pendapatan peternak yaitu pada musim kemarau 12,62 dan 1,02 pada musim penghujan (Tabel 10). Hasil tersebut menunjukkan bahwa usaha peternakan sapi menguntungkan. R/C Ratio musim kemarau jauh lebih besar jika dibandingkan pada musim penghujan karena pada musim kemarau peternak tidak mengeluarkan biaya untuk pakan ternak, pada musim penghujan peternak mengeluarkan biaya pakan dari lahan pertanian yang disisihkan dan melakukan sewa lahan.

Sapi di Desa Ajuraja sangat berpeluang untuk dikembangkan dan dapat memberikan sumbangan pendapatan yang besar bagi peternak terutama pada musim kemarau karena tidak ada pemasukan dari hasil pertanian dan peternak hanya mengandalkan penerimaan dari sapi yang dijual, tetapi karena sistem pemeliharaan yang masih bersifat ekstensif dan tradisional sehingga pendapatan dari pemeliharaan sapi masih rendah. Pendapatan peternak dapat ditingkatkan melalui 
perbaikan sistem pemeliharaan sapi, dengan memperbaiki sistem pemeliharaan maka akan menguntungkan dan akan memunculkan keunggulan sapi Bali, tetapi didaerah penelitian keunggulan tersebut belum nampak karena sistem pemeliharaan yang masih bersifat ekstensif dan tradisional.

\section{KESIMPULAN}

Pendapatan peternak pada musim kemarau lebih besar dibandingkan pada musim penghujan. Hal ini disebabkan karena peternak mengeluarkan biaya pakan pada musim penghujan sedangkan pada musim kemarau peternak tidak mengeluarkan biaya untuk pakan.

\section{DAFTAR PUSTAKA}

Badan Pusat Statistik. (2014). Wajo Dalam Angka 2017. Wajo: Badan Pusat Statistik Kabupaten Wajo. Badan Pusat Statistik. (2017). Wajo Dalam Angka 2017. Wajo: Badan Pusat Statistik Kabupaten Wajo. Dinas Pertanian Kabupaten Wajo. (2015). Statistik Peternakan. Sengkang: Dinas Pertanian Kabupaten Wajo.

Entwistle K \& Lindsay, D.R. (ed). (2003). Strategies to improve Bali cattle in astern Indonesia. ACIAR Proceedings No. 110, Canberra: Aciar.

Lisson, S., MacLeod, N., McDonald, C., Corfield, J., Pengelly, B., Wirajaswadi, L., Rahman, R., Bahar, S., Padjung, R., Razak, N., Puspadi, K., Sutaryono, Y., Saenong, S., Panjaitan, T., Hadiawati, L., Ash, A, \& Brennan, L. (2010). A participatory, farming systems approach to improving Bali cattle production in the smallholder crop-livestock systems of Eastern Indonesia. Agricultural System, 103(7), 486-497. https://doi.org/10.1016/j.agsy.2010.05.002

Martojo H. (2003). Indigenous Bali Cattle: The Best Suited Cattle Breed Forsustainable Small Farms In Indonesia. Laboratory of Animal Breeding and Genetics, Faculty of Animal Science. Bogor: IPB Press.

Meta, A. (2018). Analisis tingkat mortalitas Sapi Bali pada pemeliharaan tradisional di Kecamatan Nanaet Dubesi Kabupaten Belu. Journal of Animal Science, 3(3), 43-46. https://doi.org/10.32938/ja.v3i3.538

Page, B., Sothoeun, S., Pha, K., Savouth, H., \& Bush, R. (2011). A field study of target feeding forages to Bos Indicus beef cattle in southern cambodia. In: Cattle Health, Production and Trade in Cambodia. Young, J., Rast, L., Sosthoeun, S., \& Windsor, P. Phnom Penh, Cambodia: ACIAR. pp 34-40.

Soekartawi. (1995). Analisis Usahatani. Jakarta: Universitas Indonesia Press. pp 58.

Susanti, A. E. (2015). Estimasi Dinamika Populasi dan Produktivitas Sapi Potong di Kabupaten Banyuasin Provinsi Sumatera Selatan. Tesis. Yogyakarta: Program Pascasarjana, Fakultas Peternakan, Universitas Gadjah Mada.

Sutarno \& Setyawan, A. D. (2015). Review: Genetic diversity of local and exoticcattle and their crossbreeding impact on the quality of Indonesian cattle. Biodiversitas, 16, 327-354. https://doi.org/10.13057/biodiv/d160230

Sutarno. (2010). Genetic variation among Indonesian native cattle breeds based on polymorphisms analysis in the growth hormone loci and mitochondrial DNA. Biodiversitas, 11, 1-4. https://doi.org/10.13057/biodiv/d110101 